\title{
Bin idh
}

\section{gewerbeftener=

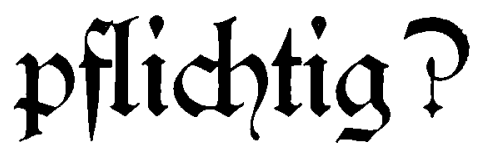

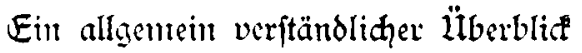

iuber

\section{Sas neute $(\mathfrak{G e n e r b e f t e u t e r g e r}$}

und jugleidf

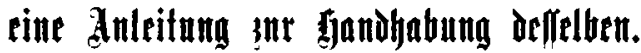

\section{Win}

\section{Dr. p. (Bünther,}

Siegicnutus=?

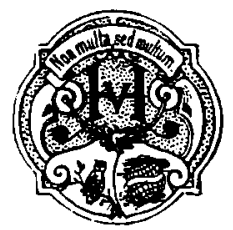

20rfin 1892.

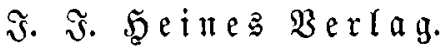

